\title{
The influence of TNF- $\alpha$ on the expression profile of key enzymes of steroidogenesis in H295R cells
}

\author{
Beniamin Grabarek ${ }^{1,2,3}$, Krzysztof Cholewa ${ }^{3}$, Jolanta Lodowska ${ }^{3}$ \\ ${ }^{1}$ Department of Histology, Cytophysiology and Embryology, Faculty of Medicine, University of Technology, Zabrze, Poland \\ 2Department of Biochemistry, Faculty of Pharmaceutical Sciences in Sosnowiec, Medical University of Silesia in Katowice, Poland \\ ${ }^{3}$ Maria Sklodowska-Curie National Institute of Oncology, Krakow, Poland \\ DOI: \\ Adv Dermatol Allergol 2021; XXXVIII (3): 404-411 \\ https://doi.org/10.5114/ada.2021.107926
}

\begin{abstract}
Introduction: Tumor necrosis factor- $\alpha$ (TNF- $\alpha$ ) plays an extremely important role in the regulation of hypothalamicpituitary-adrenal axis. It is believed that chronic inflammation is the main cause of cancerogenesis and TNF- $\alpha$ plays a significant role in both of these processes. Unfortunately, the function of TNF- $\alpha$ in human adrenal steroidogenesis has not been explained enough.

Aim: To evaluate the changes in transcriptional activity of STAR, CYP11A1, CYP11B1, and CYP11B2 in H295R cell line exposed to TNF- $\alpha$.

Material and methods: $\mathrm{NCl}-\mathrm{H} 295 \mathrm{R}$, human adrenocortical cell line was exposed to human recombinant TNF- $\alpha$ at the concentrations ranging from 0.001 to $10 \mathrm{nM}$ for 3, 12, 24, and $48 \mathrm{~h}$. Cells not exposed to TNF- $\alpha$ were the control of this experiment. RTqPCR assay was used to determine the changes in the expression of genes encoding STAR, CYP11A1, CYP11B1, and CYP11B2.

Results: The highest differences between stimulated and non-stimulated cells were observed in the expression of STAR (FC = +2.2; $0.01 \mathrm{nM}$ of TNF- $\alpha ; 48 \mathrm{~h})$; CYP11A1 (FC = +3.5; $0.1 \mathrm{nM}$ of TNF- $\alpha ; 24 \mathrm{~h}) ;$ CYP11B1 (FC $=+7.0 ; 10 \mathrm{nM}$ of TNF- $\alpha ; 48$ h); CYP11B2 (FC $=+2.5 ; 10 \mathrm{nM}$ of TNF- $\alpha ; 48 \mathrm{~h}$ ). Statistically significant differences $(p<0.05)$ in the expression were found only for CYP11A1. The interaction effect between genes was also noticed $(p<0.05)$.

Conclusions: The research showed the impact of TNF- $\alpha$ on the expression of the key genes encoding enzymes involved in adrenal steroidogenesis. Different expression patterns of was observed, depending on time and TNF- $\alpha$ concentration increased synthesis of this pro-inflammatory cytokine may intensify adrenal steroidogenesis..
\end{abstract}

Key words: tumor necrosis factor- $\alpha$, steroidogenesis, cancer, adrenal glands, H295R cells.

\section{Introduction}

Tumor necrosis factor- $\alpha$ (TNF- $\alpha$ ) is a pleiotropic, proinflammatory cytokine produced by many cell types including monocytes, macrophages, T-lymphocytes and mast cells. This cytokine is also known as either cachectin or differentiation-inducing factor (DIF). It participates in a large number of biological events such as prostaglandin and leukotriene secretion, reactive form of oxygen (RFT) production and regulation of the expression of the gene, e.g. c-fos, c-jun [1]. Its negative relationship with the cardiovascular system was documented by several reports [2-5].
TNF- $\alpha$ is widely considered as an important inflammatory mediator of many human diseases such as autoimmune diseases, cancer, hypernociception, cardiovascular diseases and fibrosis [6].

According to some studies, TNF- $\alpha$ plays a crucial role in the regulation of the hypothalamic-pituitary-adrenal axis. This cytokine increases corticotropin-releasing hormone $(\mathrm{CRH})$ secretion by the hypothalamus, what leads to increased adrenocorticotropic hormone (ACTH) release by the pituitary gland and consequently, stimulates the adrenal steroidogenesis [7].

TNF- $\alpha$ activates many intracellular signalling pathways via binding to 2 distinct cell-surface receptors,

Address for correspondence: Beniamin Grabarek PhD, Department of Histology, Cytophysiology and Embryology, Faculty of Medicine, University of Technology, Zabrze, Poland, phone: +48 1236484 80, e-mail: bgrabarek7@gmail.com Received: 2.01.2020, accepted: 11.01.2020. 
TNFR1 and TNFR2, what leads to two opposite effects, apoptosis or survival by activating classical NF-кB signalling pathway $[1,8,9]$.

The first of the receptors is expressed mostly on the surface of nucleated cells whereas TNFR2 could be found on immune cells such as lymphocytes, macrophages, thymocytes and also fibroblasts, as well as endothelial cells [2, 10].

Moreover, TNF- $\alpha$ and its receptors are expressed in the hypothalamus and anterior pituitary gland where TNF- $\alpha$ is involved in the communication between the immune system and the hypothalamus-pituitary-adrenal axis [11, 12].

Depending on the TNF- $\alpha$ concentration in tumour microenvironment, promotion of tumour growth or necrosis of tumour cells could occur. A low concentration of TNF- $\alpha$ has been shown to stimulate tumour growth whereas its higher concentration might have a cytotoxic and antiproliferative effect $[13,14]$.

Numerous reports have shown that TNF- $\alpha$ participates in every aspect of cancerogenesis such as transformation, angiogenesis, metastasis, survival and migration of tumour cells.

It is proved that chronic inflammation is the main cause of cancerogenesis and studies have linked TNF- $\alpha$ to this process [15]. There is evidence that the expression of TNF- $\alpha$ is increased in a large number of pre-neoplastic cells and tumour tissue. It is suggested to be a useful marker of cancer development and chemotherapy effectiveness; its concentration in serum has been shown to following decreased therapy, i.e., in prostate and breast cancer patients [16-18].

The cancerous process may also take place in endocrine tissues, including the adrenal cortex gland where several different histological types of tumours can occur.

The first type of glandular cancer is adenoma, which is located in the cortex of the adrenal gland. Its cells can or cannot have the ability to secrete zone-specific, cortex hormones such as glucocorticoids, mineralocorticoids and androgens. Excretory active carcinomas are associated mostly with ACTH - independent Cushing's syndrome (due to hypersecretion of glucocorticoids, mainly cortisol) or Conn's syndrome (hypersecretion of aldosterone). Both diseases could be connected with hypertension which is a proinflammatory disease [19-21] and could cause other negative changes in the cardiovascular system [22, 23].

The second type of endocrine carcinoma is cortex carcinomas which have hormonal activity in $62 \%$ of patients. It is worth mentioning that the patient's average age of tumour manifestation is 24 years and that women have more frequently the excretive type of carcinoma while hormonally inactive tumours are characteristic of men over 40 years [24].

Because the role of TNF- $\alpha$ in human adrenal steroidogenesis is still unclear and not fully investigated, the aim of this study was to examine the effect of TNF- $\alpha$ on steroidogenesis by testing the influence of this cytokine on the expression of key genes which encode the selected enzymes of the steroidogenesis pathway in adrenal gland cells.

Steroidogenic acute regulatory protein (STAR) plays a key role in the acute regulation of steroid hormone synthesis by enhancing the conversion of cholesterol into pregnenolone. Cholesterol side-chain cleavage enzyme (CYP11A1) is a monooxygenase which catalyses many reactions involved in drug metabolism and synthesis of cholesterol, other steroids and lipids. Steroid $11 \beta$-hydroxylase (CYP11B1), localized on the mitochondrial inner membrane, is involved in the conversion of progesterone to cortisol in the adrenal cortex. Aldosterone synthase cytochrome P-450 (CYP11B2) has steroid 18-hydroxylase activity and synthesizes aldosterone and 18-oxocortisol. In the research, human adrenocortical cell line $\mathrm{NCl}-\mathrm{H} 295 \mathrm{R}$ was used; in the literature data this cell line has been described as a useful model to study the adrenocortical steroidogenesis pathway [25-27].

\section{Material and methods}

\section{Cell culture}

$\mathrm{NCl}-\mathrm{H} 295 \mathrm{R}$, human adrenocortical cell line was obtained from the Cell Lines Service (CLS). The medium DMEM: Ham's F12 (CLS, catalogue ID. 820402), containing $15 \mathrm{mM}$ bovine serum albumin, $0.00535 \mathrm{mg} / \mathrm{ml}$ linoleic acid, $2.5 \%$ Nu-Serum I and supplemented with antibiotics (1000 IU/ml penicillin, $10 \mathrm{mg} / \mathrm{ml}$ streptomycin) was used in the experiment. The cell cultures were maintained as monolayers at $37^{\circ} \mathrm{C}$ in a $5 \% \mathrm{CO}_{2}$ humidified atmosphere. Cells were seeded at the density of $1 \times 10^{6}$ cells/well on six-well plastic cell culture dishes and cultured for $24 \mathrm{~h}$. They were then treated with different concentrations (0.001-10 nM) of recombinant human TNF- $\alpha$ (PEPROTECH, catalogue ID. 300-01A). The cells in the control culture were supplemented with a medium containing no test substance. After 3, 12, 24, $48 \mathrm{~h}$ the cells were collected for total RNA extraction. In this experiment, each concentration of TNF- $\alpha$ corresponds to a letter of the alphabet ( $A$ is $0.001 \mathrm{nM}, \mathrm{B}$ is $0.01 \mathrm{nM}, \mathrm{C}$ is $0.1 \mathrm{nM}, \mathrm{D}$ is $1 \mathrm{nM}$ and $\mathrm{E}$ is $10 \mathrm{nM}$ of TNF- $\alpha$ ). Results for each time of exposure and every concentration of TNF- $\alpha$ used in this experiment were assessed twice.

\section{RNA extraction, RT-QPCR}

Total RNA was isolated from cultured cells with the use of TRIzol reagent (Invitrogen, USA), according to the manufacturer's protocol. The concentration of RNA was measured spectrophotometrically at $260 \mathrm{~nm}$. For reverse transcription - quantitative polymerase chain reaction (RT-QPCR) test QuantiTect Fast kit (Qiagen, USA) was used. All procedures were carefully followed according to the protocol described in QuantiFast ${ }^{\oplus}$ Probe RT-PCR Handbook. The reaction was performed in the following steps: reverse transcription: 10 min at $50^{\circ} \mathrm{C}$, activation: $5 \mathrm{~min}$ at $95^{\circ} \mathrm{C}$, and $10 \mathrm{~s}$ at $95^{\circ} \mathrm{C}$, 
$30 \mathrm{~s}$ at $60^{\circ} \mathrm{C}$ (40 cycles). RTqPCR was carried out with CFX Connect (Bio-Rad) test using commercially available gene specific fluorescent real-time PCR primers and probes of Gene Expression Assays (Applied Biosystems) for STAR (assay ID. Hs00264912_m1), cholesterol side chain cleavage enzyme (CYP11A1, assay ID. Hs0016784 m1), steroid $11 \beta$-hydroxylase (CYP11B1, assay ID Hs01596404_m1), aldosterone synthase cytochrome P-450 (CYP11B2, assay ID Hs01597732_m1) and glyceraldehyde-3-phosphatate dehydrogenase (GAPDH, assay ID Hs02758991_g1) as an endogenous control.

Specificity of the amplification reaction for all fragments of tested genes was assessed by means of polyacrylamide gel electrophoresis. Each sample was examined in two repetitions, and for each the threshold amplification value was calculated (threshold cycle-Ct). According to the definition, $\mathrm{Ct}$ is the moment in which the level of fluorescence exceeds the line that separates background fluorescence and fluorescence of the probe after RT-QPCR reaction. The analysis of results has been performed by comparing the $C t$ values. For statistical analysis, the $2^{-\Delta \Delta c t}$ value was calculated. The calculation of standardized value of the relative gene expression level in an unknown sample, in relation to control, was performed in accordance to the formula $R=2^{-\Delta \Delta c t}$. The obtained results were expressed as multiplicity of the calibration sample. The value of parameter $R$ equal to 1 means that the level of the gene expression in the calibration sample and the unknown sample are the same. The value lower than 1 indicates a higher level of expression in the calibration sample, while

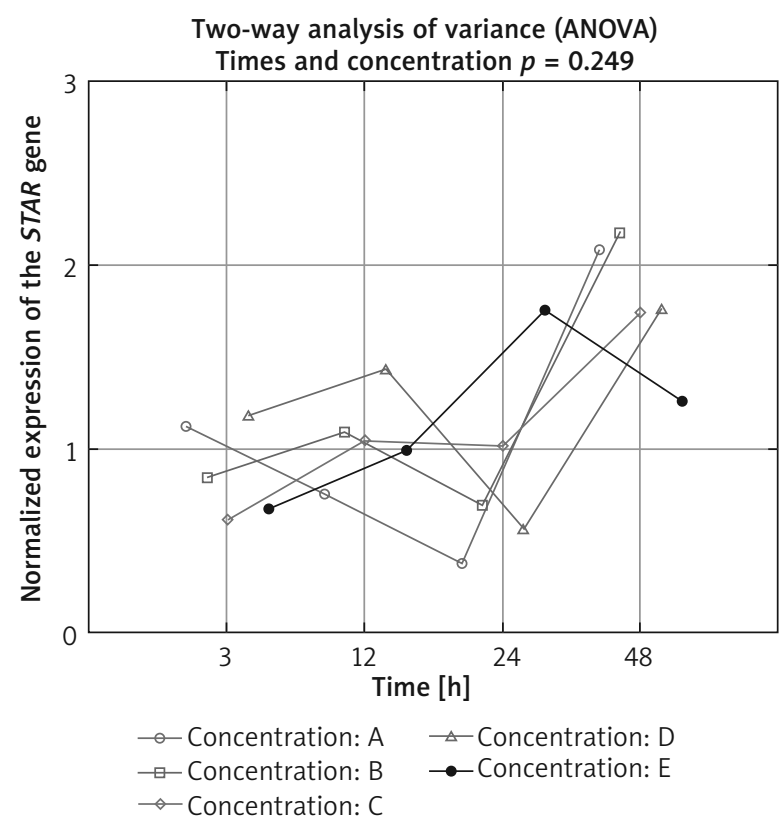

Figure 1. Two-way analysis of variance for normalized expression of the STAR gene. Time of incubation of $\mathrm{NCl} 295 \mathrm{R}$ cells with TNF- $\alpha$ was 3 h, 12 h, $24 \mathrm{~h}$, and $48 \mathrm{~h}$. Concentration of the cytokine was $A=0.001 \mathrm{nM}, B=0.01 \mathrm{nM}, C=0.1 \mathrm{nM}$, $\mathrm{D}=1 \mathrm{nM}$ and $\mathrm{E}=10 \mathrm{nM}$ the results exceeding 1 indicates a higher expression in the unknown sample, in comparison with the reference sample.

\section{Statistical analysis}

Data were analysed using the statistical programme Statistica 12PL. Firstly, data were analysed by ShapiroWilk test which proved that results had a Gaussian distribution. The dependence between time and concentration of TNF- $\alpha$ and gene expression levels was analysed by two-way analysis of variance (ANOVA), applying lambda Wilk's statistic. In this experiment, the correlation between three agents, mainly: time, dose of proinflammatory cytokine and gene expression was analysed by three-way analysis of variance (ANOVA). Post-hoc NIR test was used when the differences were statistically significant. The level of significance was set at $p<0.05$.

\section{Results}

\section{Two-way analysis of variance (ANOVA)}

This analysis was made to investigate the influence of incubation time and different TNF- $\alpha$ concentrations on gene expression changes in $\mathrm{NCl}-295 \mathrm{R}$ cells. This analysis was made for every single gene.

\section{Two-way analysis of variance (ANOVA) for STAR}

Expression of the gene which encodes STAR protein increased approx. 1.5-fold after $48 \mathrm{~h}$ incubation at all TNF- $\alpha$ concentrations tested. After short incubation time (3-12 h) no significant gene expression changes were observed. The biggest differences in STAR gene expression were calculated after $24 \mathrm{~h}$ incubation, but the results had no statistical significance (Figure 1).

\section{Two-way analysis of variance (ANOVA) for CYP11A1}

The results showed that a short incubation time and low concentration of tested cytokine caused a higher CYP11A1 gene expression which was decreasing at higher doses of TNF- $\alpha$. The most significant change was observed after $24 \mathrm{~h}$. The maximal increase of gene expression was detected after $24 \mathrm{~h}$ treatment with $0.1 \mathrm{nM}$ of TNF- $\alpha$ concentration and this change was statistically significant.

What is more, because the CYP11A1 gene expression differences were substantial, the post-hoc NIR test was used. The differences between the expression of this gene and concentration of TNF- $\alpha$ at all doses after $24 \mathrm{~h}$, and after $3 \mathrm{~h}$ between concentrations: A, D, E and between 12 and 24 h' time periods for higher concentrations (C, D, E) occurred to be significant (Figure 2).

\section{Two-way analysis of variance (ANOVA) for CYP11B1}

The expression profile of the gene encoding CYP11B1 showed that the prolongation of the incubation time and 


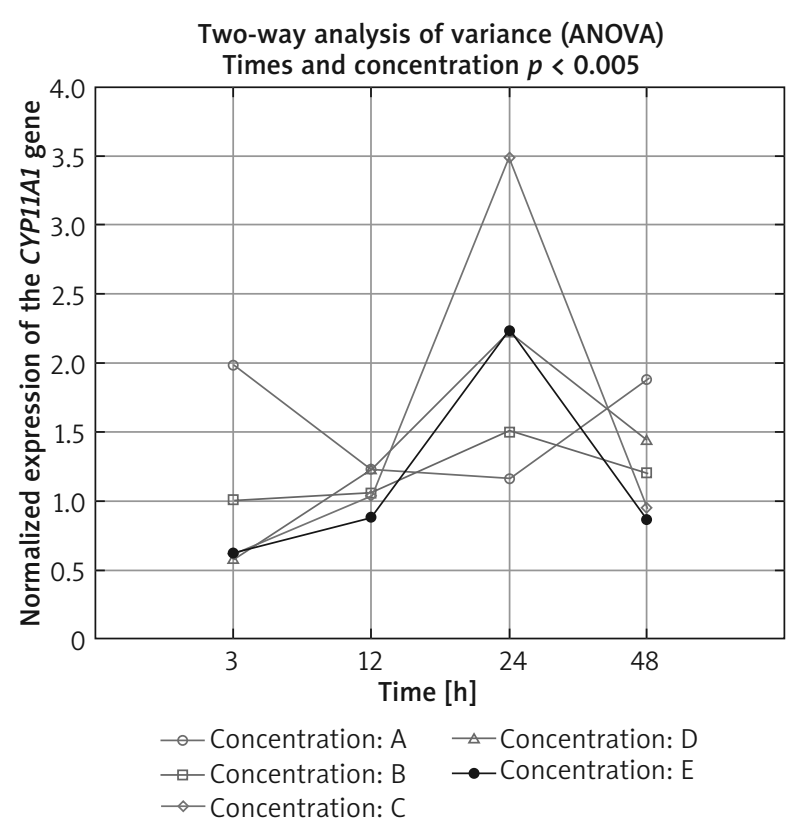

Figure 2. Two-way analysis of variance for normalized expression of the CYP11A1 gene. Time of incubation of $\mathrm{NCl} 295 \mathrm{R}$ cells with TNF- $\alpha$ was $3 \mathrm{~h}, 12 \mathrm{~h}, 24 \mathrm{~h}$, and $48 \mathrm{~h}$. Concentration of the tested cytokine was $A=0.001 \mathrm{nM}$, $\mathrm{B}=0.01 \mathrm{nM}, \mathrm{C}=0.1 \mathrm{nM}, \mathrm{D}=1 \mathrm{nM}$ and $\mathrm{E}=10 \mathrm{nM}$

the higher concentration of TNF- $\alpha$ increase the expression of the tested gene. The 48-hour effect of the tested cytokine at each of the concentrations used, increased the expression of the gene encoding CYP11B1 from 2 to almost 7 times. Differences in expression depending on time were statistically significant. The highest increase was observed after the longest incubation period and the highest concentration of TNF- $\alpha$. After $12 \mathrm{~h}$, the level of expression at almost all concentrations, after initial silencing, reached a level comparable to the control and was increasing with prolongation of the incubation time. In contrast to concentration, a significant effect of TNF- $\alpha$ intoxication time was observed - it caused an increase in normalized expression of the CYP11B1 gene (Figure 3).

\section{Two-way analysis of variance (ANOVA) for CYP11B2}

Comparable results were obtained for CYP11B2 gene expression. A short incubation period with TNF- $\alpha$ at all used concentrations resulted in decreasing expression of CYP11B2. Furthermore, expression increased with the usage of higher concentrations and longer incubation period. The maximum effect of TNF- $\alpha$ was observed after $48 \mathrm{~h}$ and with $10 \mathrm{nM}$ concentration (up to 2.5 fold), but the increase in CYP11B2 gene expression was not as significant as that for CYP11B1 expression (Figure 4).

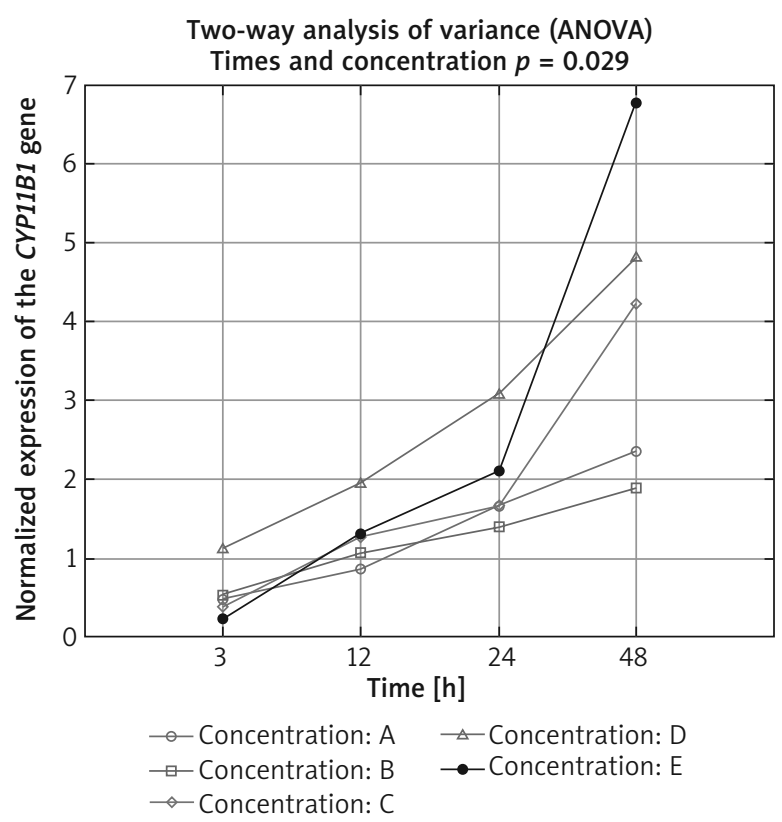

Figure 3. Two-way analysis of variance for normalized expression of the CYP11B1 gene. Time of incubation of $\mathrm{NCl}$ $295 \mathrm{R}$ cells with TNF- $\alpha$ was 3 h, 12 h, 24 h, and 48 h. Concentration of the cytokine was $A=0.001 \mathrm{nM}, \mathrm{B}=0.01 \mathrm{nM}$, $\mathrm{C}=0.1 \mathrm{nM}, \mathrm{D}=1 \mathrm{nM}$ and $\mathrm{E}=10 \mathrm{nM}$

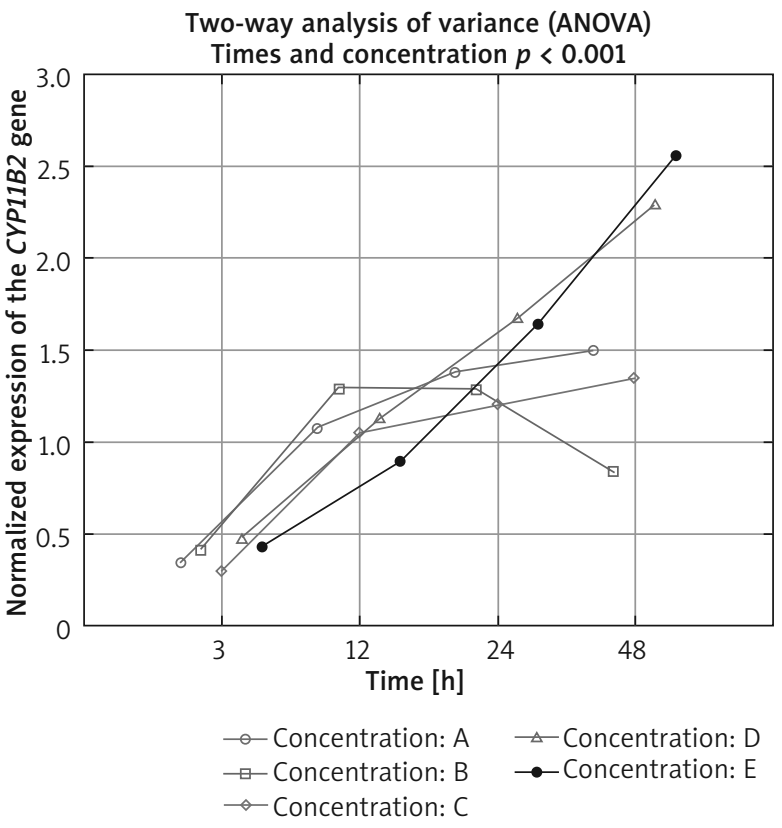

Figure 4. Two-way analysis of variance for normalized expression of the CYP11B2 gene. Time of incubation of $\mathrm{NCl}$ 295R cells with TNF- $\alpha$ was 3 h, 12 h, 24 h, and 48 h. Concentration of the cytokine was $A=0.001 \mathrm{nM}, B=0.01 \mathrm{nM}$, $\mathrm{C}=0.1 \mathrm{nM}, \mathrm{D}=1 \mathrm{nM}$ and $\mathrm{E}=10 \mathrm{nM}$ 


\section{Three-way analysis of variance (ANOVA)}

This analysis was made to investigate the relation between three factors (incubation time, dose of TNF- $\alpha$, level of gene expression) and gene expression changes.

It was made in two variants. When all 4 genes were taken into account, the results had no statistical significance. However, when the gene which codes STAR protein was omitted, three-way analysis of variance showed significant differences between samples.

The strongest relationship between the concentration of the test compound and the time of incubation and gene expression was observed for the CYP11A1 gene after $24 \mathrm{~h}$ and TNF- $\alpha \mathrm{C}$ concentration and after $48 \mathrm{~h}$ and D concentration of the cytokine.

This kind of relationship was seen also for the expression of the CYP11B1 gene after $48 \mathrm{~h}$ and both $\mathrm{C}$ and E concentrations of TNF- $\alpha$.

Finally, it could be observed that there was no association between short time of incubation and low doses of TNF- $\alpha$ and significant changes in gene expression. A statistically significant relation was found only with the use of higher concentrations and longer incubation time. It was also confirmed that analysed genes could affect each other's expression. This may suggest that the expression of the STAR gene could not be related to different TNF- $\alpha$ concentrations (Figure 5).

\section{Discussion}

We investigated the time and dose-dependent effects of TNF- $\alpha$ on the expression of genes coding for selected enzymes involved in adrenal steroidogenesis in $\mathrm{NCl}-\mathrm{H} 295 \mathrm{R}$ adherent cell line as an experimental model. This cell line differs from parental cell line NCl-295 only in the proliferation rate and the ability of adhesion [25]. In the study, the expression of four genes: STAR and three genes coding the cytochrome P450 enzyme family which are directly associated with adrenal steroidogenesis pathway, i.e., CYP11A1, CYP11B1, CYP11B2 [28] was tested.

The present study was aimed at the understanding of the influence of one of the main proinflammatory cytokines on the steroidogenesis as the effects of TNF- $\alpha$

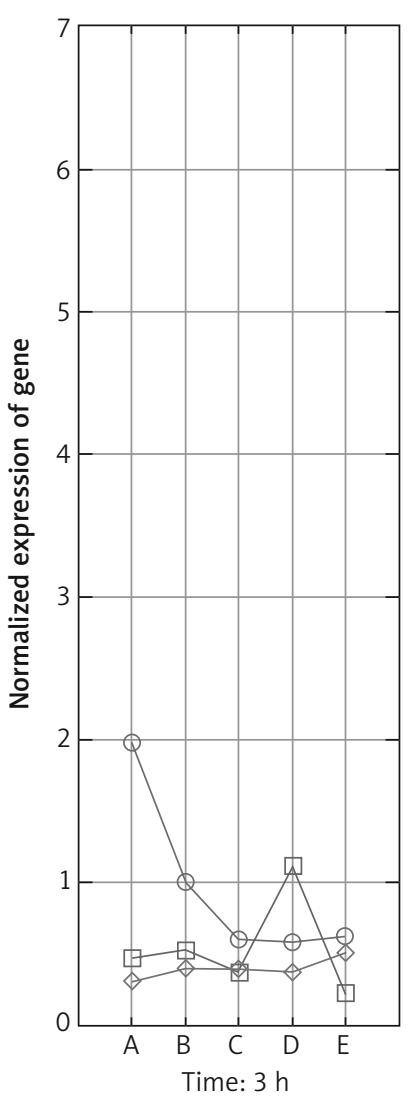

(ANOVA)

Time, gene, concentration $p=0.036$
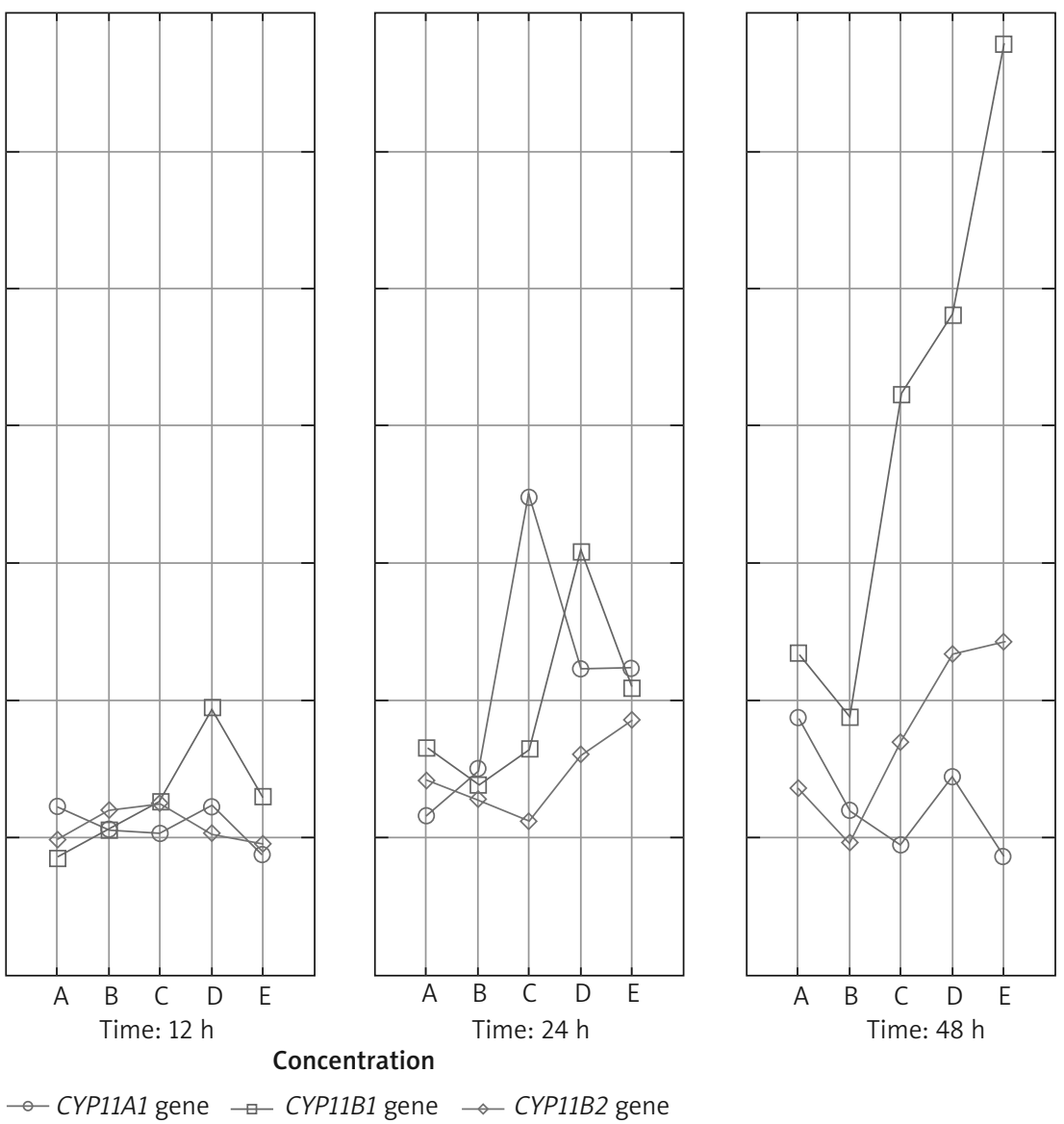

$\multimap$ CYP11A1 gene $\square$ CYP11B1 gene $\multimap$ CYP11B2 gene

Figure 5. Three-way analysis of variance for normalized expression of CYP11A1, CYP11B1 and CYP11B2 genes. Time of incubation NCl 295R cells with TNF- $\alpha$ was 3 h, 12 h, $24 \mathrm{~h}$ and $48 \mathrm{~h}$. Concentration of the cytokine was $A=0.001 \mathrm{nM}$, $\mathrm{B}=0.01 \mathrm{nM}, \mathrm{C}=0.1 \mathrm{nM}, \mathrm{D}=1 \mathrm{nM}$ and $\mathrm{E}=10 \mathrm{nM}$ 
on this process have not been studied and described enough, as yet.

The first of the examined gene STAR is known to play an extremely important role in the steroidogenesis pathway $[29,30]$. The protein encoded by the STAR gene takes part in the transport of cholesterol molecules (precursor in steroidogenesis) from the outer to the inner membrane of mitochondrion. Gazdar et al. tested the ability of parental cells of $\mathrm{NCl}-\mathrm{H} 295$ line to produce cholesterol itself using cholesterol and serum free medium [26].

The ability of production by adrenal cells makes adrenals partly independent of external sources of cholesterol. The current experiment shows that the expression of the gene coding for STAR protein increased after a long incubation time with TNF- $\alpha$. After $48 \mathrm{~h}$ incubation, the gene expression increased 2-fold, however, it was observed only with the use of A and B TNF- $\alpha$. Higher concentrations of the tested cytokine caused the decrease in STAR expression, but these changes were not statistically significant.

The present study could be compared with the findings of Mikhaylova et al. who have used 1 nM TNF- $\alpha$ to stimulate $\mathrm{NCl}-\mathrm{H} 295 \mathrm{R}$ cells for $48 \mathrm{~h}$ and observed a 1.7fold increase in the STAR gene expression; in our experiment the level of this gene expression rose up to 1.76- fold compared to the control under the same circumstances [31].

Our results have shown that low TNF- $\alpha$ doses and short incubation time are associated with a decreased level of STAR expression. It might suggest the reduction in STAR protein amount and in consequence a short and slightly inflammatory process which will not stimulate cancerogenesis in the adrenal gland. The secretion of TNF- $\alpha$ may have not a significant impact on the amount of STAR protein. Perhaps even with the involvement of hormones in the synthesis, the STAR protein activity is sufficient to cover the cellular demand for cholesterol. However, after prolonged stimulation, the expression of this gene was increasing, what could be attributed to the inhibition of steroid compounds synthesis. Mikhaylova et al. have demonstrated that after $48 \mathrm{~h}$ incubation of $\mathrm{NCl}-\mathrm{H} 295 \mathrm{R}$ cells with $1 \mathrm{nM}$ TNF- $\alpha$, the amount of STAR protein has increased. It might be evidence that this proinflammatory cytokine can regulate both the STAR gene expression and the amount of STAR protein [32].

In the research, the stimulatory effect of TNF- $\alpha$ on the CYP11A1 gene expression was also studied. The enzyme encoded this gene catalyses a key, rate-limiting step in the biosynthesis of adrenal hormones. Our results show that TNF- $\alpha$ has the ability to regulate intermediate and final steps of the adrenal steroidogenesis pathway. Moreover, the incubation time has been shown to play an important role in expression of the CYP11A1 gene. The gene expression increased only after $24 \mathrm{~h}$ incubation with the use of 10 nM TNF- $\alpha$ while after 3, 12, and 48 h periods, opposite effects (lower gene expression) were observed.
The influence of TNF- $\alpha$ on secretion of adrenal hormones is dependent on the developmental stage of this organ and the species [33, 34].

The next examined gene was CYP11B1. CYP11B1 encodes the last enzyme of the biosynthetic pathway for cortisol production. We observed huge differences in CYP11B1 expression after stimulation with the TNF- $\alpha$ cytokine. The study showed that the increasing concentration and prolonged incubation time caused a higher expression of CYP11B1. It is comparable to Mikhaylova et al. research where the scientists used 1 nM TNF- $\alpha$ to stimulate cells within 3-48 h. The influence of this cytokine on secretion of cortisol was observed only after $48 \mathrm{~h}$ [31]. Our results showed that expression of the mRNA for CYP11B1 increased after $24 \mathrm{~h}$ and after the next day of incubation the level of expression was 5-fold higher than in the control. It may be a result of response leading to the reduction of inflammation or be associated with specify of specific cell culture model, what is in agreement with results of Lichtenauer et al. [35]. According to their results, $\mathrm{NCl}-\mathrm{H} 295 \mathrm{R}$ cells favour the synthesis of cortisol over that of other adrenal hormones [26, 36, 37].

The last analysed gene CYP11B2 takes part in synthesis of aldosterone. The studies have demonstrated a lower level of CYP11B2 gene expression in adrenal adenomas characterized by cortisol secretion [38]. In the tested NCl-H295R cell line TNF- $\alpha$ increased the expression of the CYP11B2 gene. There is evidence that TNF- $\alpha$ stimulates CYP11B2 expression. In their experiment, Mikhaylova et al. have used NCI-H295R cells as a model to observe increasing secretion of aldosterone after treatment with1 nM TNF- $\alpha$ [31]. However, the effect of TNF- $\alpha$ on CYP11B2 gene expression was not as significant as the effect of the tested cytokine on CYP11B1 expression. We found that the influence of TNF- $\alpha$ on the genes coding for selected enzymes of the steroidogenesis pathway in the adrenal gland is comparable to the statement that steroidogenesis is a sophisticated process.

It has been proven that cancerogenesis is associated with inflammation. Stimulated immune cells accumulate in inflammation foci where they can secrete various types of cytokines i.e. TNF- $\alpha$ [39]. Because macrophages and adrenal cells are the main source of inflammation cytokines, during cancer transformation, when the number of macrophages is increasing, the level of TNF- $\alpha$ also increases. Macrophages modify tumour microenvironment causing tumour progression [40-43].

Based on this study, it can be stated that the increased synthesis of pro-inflammatory cytokines can cause intensification of steroidogenesis, as indicated by the increasing transcript levels of tested genes independently of hormonal activity of the tumour. Uncontrolled steroidogenesis may lead to an increase in the concentration and activity of aldosterone and cortisol, which can result in many adverse clinical implications. 


\section{Conclusions}

TNF- $\alpha$ has a regulatory activity in steroidogenesis in adrenal cells. Its effects on the expression of genes coding for selected enzymes of the steroidogenesis pathway seem to be complex because they have been shown to be dependent on the incubation time, TNF- $\alpha$ concentration and the type of the gene expression of which undergoes modulation.

Further research should be carried out for better understanding of the adrenal steroidogenesis pathway.

\section{Acknowledgments}

All authors were responsible for the concept and design of the study, collection and collation of data, analysis and interpretation of data, writing of the article, reviewing, and final reviewing of this article and graphics performance.

\section{Conflict of interest}

The authors declare no conflict of interest.

\section{References}

1. Ahmad S, Azid NA, Boer JC, et al. The key role of TNF-TNFR2 interactions in the modulation of allergic inflammation: a review. Front Immunol 2018; 9: 2572.

2. Grabarek B, Bednarczyk M, Mazurek U. The characterization of tumor necrosis alpha (TNF- $\alpha$ ), its role in cancerogenesis and cardiovascular system diseases and possibilities of using this cytokine as a molecular marker. Univ Lodz Folia Biol Oecol 2017; 13: 1-8.

3. Badawi A, El-Hamid A, Mohamed N, et al. Serum tumor necrosis factor (TNF)-like weak inducer of apoptosis (TWEAK) and leptin as biomarkers of accelerated atherosclerosis in patients with systemic lupus erythematosus and antiphospholipid syndrome. Egypt Rheumatol 2017; 39: 75-81.

4. Kroetsch JT, Levy AS, Zhang H, et al. Constitutive smooth muscle tumour necrosis factor regulates microvascular myogenic responsiveness and systemic blood pressure. Nat Commun 2017; 8: 14805.

5. Maaten JM, Damman K, Verhaar MC, et al. Connecting heart failure with preserved ejection fraction and renal dysfunction: the role of endothelial dysfunction and inflammation. Eur J Heart Fail 2016; 18: 588-98.

6. Kalliolias GD, Ivashkiv LB. TNF- $\alpha$ biology, pathogenic mechanisms and emerging therapeutic strategies. Nat Rev Rheumatol 2016; 12: 49-62.

7. Guzman C, Hernandez-Bello R, Morales-Montor J. Regulation of steroidogenesis in reproductive, adrenal and neural tissues by cytokine. Open Neuroendocrinol J 2010; 3: 161-9.

8. Muller J, Baeyens A, Dustin M. Tumor necrosis factor receptor superfamily in T cell priming and effector function. Adv Immunol 2018; 141: 51-57.

9. Feltham RL, Moulin M, Vince JE, et al. Tumor necrosis factor (TNF) signaling, but not TWEAK (TNF-like weak inducer of apoptosis)-triggered cIAP1 (cellular inhibitor of apoptosis protein 1) degradation, requires CIAP1 RING dimerization and E2 binding. J Biol Chem 2017; 292: 14310.
10. Korobowicz A. Biologia czynnika martwicy nowotworów typu alfa (TNF- $\alpha$ ). Pol Merk Lek 2006; 21: 358-61.

11. Mariotti S, Beck-Peccoz P. Physiology of the hypothalamicpituitary-thyroid axis. Endotext 2016; 14.

12. Margioris AN, Tsatsanis C. CTH Action on the Adrenals. Endotext 2016; 14.

13. Tse BWC, Scott KE. Russell, P.J. Paradoxical roles of tumor necrosis factor-alpha in prostate cancer biology. Prostate Cancer 2012; 2012: 128965.

14. Roubert A, Gregory K, Li Y, et al. The influence of tumor necrosis factor- $\alpha$ on the tumorigenic Wnt-signaling pathway in human mammary tissue from obese women. Oncotarget 2017; 8: 36127-36.

15. Patela HJ, Pate BM. TNF- $\alpha$ and cancer cachexia: molecular insights and clinical implications. Life Sci 2017; 170: 56-63.

16. Ma Y, Ren Y, Dai ZJ, et al. IL-6, IL-8 and TNF- $\alpha$ levels correlate with disease stage in breast cancer patients. Adv Clin Exp Med 2017; 26: 421-6.

17. Kabe AM. Tumor markers of breast cancer: new prospective. J Oncol Sci 2017; 3: 5-11.

18. Martinez-Reza I, Díaz L, García-Becerra R. Preclinical and clinical aspects of TNF- $\alpha$ and its receptors TNFR1 and TNFR2 in breast cancer. J Biomed Sci 2017; 24: 90.

19. Assié G. Genomic insights into Cushing syndrome L'apport de la génomique dans le syndrome de Cushing. Ann d'Endocrinol 2018; 3: 119-22.

20. Lodish M, Stratakis CA. A genetic and molecular update on adrenocortical causes of Cushing syndrome. Nat Rev Endocrinol 2016; 12: 255-62.

21. Methe H, Pehlivanli S. Glucocorticoid-remediable aldosteronism in a young adult with a family history of Conn's syndrome. Clin Case Rep 2018; 6: 416-9.

22. Hasan N, Rahim A, Ahmed QMU, et al. Hypertension and recurrent hypokalaemia in young woman - a case report of primary hyperaldosteronism (Conn's syndrome). Univ Heart J 2016; 12: 102-4.

23. Vassiliadi DA, Tsagarakis S. Cardiac hypertrophy in Cushing's syndrome: if not hypertension then what? Endocrine 2017; 56: 453-5.

24. Herman K, Jarząb M, Fijołek-Warszewska A, et al. Zalecenia postępowania diagnostyczno-terapeutycznego w nowotworach złośliwych - nowotwory nadnerczy. In: Nowotwory układu wewnątrzwydzielniczego. Herman K, Jarząb M, Fijołek-Warszewska, et al. (eds.). Via Medica, Gdansk 2013; 416-7.

25. Wang T, Rainey WE. Human andrenocortical carcinoma cell lines. Mol Cell Endocrinol 2012; 351: 58-65.

26. Gazdar AF, Oie HK, Shackleton CH, et al. Establishment and characterization of a human adrenocortical carcinoma cell Line that expresses multiple pathways of steroid biosynthesis. Cancer Res 1990; 50: 5488-96.

27. Wolkow A, Aisbett B, Reynolds J, et al. Relationships between inflammatory cytokine and cortisol responses in firefighters exposed to simulated wildfire suppression work and sleep restriction. Physiol Rep 2015; 3: e12604.

28. Saito R, Terasaki N, Yamazaki M, et al. Estimation of the mechanism of adrenal action of endocrine-disrupting compounds using a computational model of adrenal steroidogenesis in NCl-H295R cells. J Toxicol 2016; 2016: 4041827.

29. Basset M, Mayhew B, Rehman K, et al. Expression profiles for steroidogensic enzymes in adrenocortical disease. J Clin Endocrinol Metab 2005; 90: 5446-55.

30. Miller WL. Steroidogenesis: unanswered questions. Trends Endocrinol Metab 2017; 28: 771-93. 
31. Mikhaylova IV, Kuulasmaa T, Jääskeläinen J, Voutilainen R. Tumor necrosis factor- $\alpha$ regulates steroidogenesis, apoptosis, and cell viability in the human adrenocortical cell line $\mathrm{NCl}$ - H295R. J Endocrinol 2007; 148: 386-92.

32. Mikhaylova IV, Jääskeläinen T, Jääskeläinen J, et al. Leukemia inhibitory factor as a regulator of steroidogenesis in human NCl-H295R adrenocortical cells. J Endocrinol 2008; 199: 435-44.

33. Rood KM, Buhimschi CS. Genetics, hormonal influences, and preterm birth. Semin Perinatol 2017; 41: 401-8.

34. Jardine D, Emond M, Meert KL, et al. A single nucleotide polymorphism in the corticotrophin receptor gene is associated with a blunted cortisol response during pediatric critical illness. Pediatr Crit Care Med 2014; 15: 698-705.

35. Lichtenauer UD, Shapiro I, Osswald A, et al. Characterization of $\mathrm{NCl}-\mathrm{H} 295 \mathrm{R}$ cells as an in vitro model of hyperaldosteronism. Horm Metab Res 2013; 45: 124-9.

36. Oskarsson A, Ullerås E, Plant KE, et al. Steroidogenic gene expression in H295R cells and the human adrenal gland: adrenotoxic effects of lindane in vitro. J Appl Toxicol 2006; 26: 484-92.

37. Cheng LC, Pai TW, Li LA. Regulation of human CYP11B1 and CYP11B2 promoters by transposable elements and conserved cis elements. Steroids 2012; 77: 100-9.

38. Fallo F, Pezzi V, Barzon L, et al. Quantitative assessment of CYP11B1 and CYP11B2 expression in aldosterone-producing adenomas. Eur J Endocrinol 2002; 147: 795-802.

39. Netea MG, Balkwill F, Dinarello CA. A guiding map for inflammation. Nat Immunol 2017; 18: 826-31.

40. Binnewies M, Roberts EW, Kersten K, et al. Understanding the tumor immune microenvironment (TIME) for effective therapy. Nat Med 2018; 24: 541-50.

41. Opławski M, Dziobek K, Adwent I, et al. Expression profile of endoglin in different grades of endometrial cancer. Curr Pharm Biotechnol 2018; 19: 990-5.

42. Kitamura T, Pollard JW, Vendrell M. Optical windows for imaging the metastatic tumour microenvironment in vivo. Trends Biotechnol 2017; 35: 5-8.

43. Goswami KK, Ghosh T, Ghosh S, et al. Tumor promoting role of anti-tumor macrophages in tumor microenvironment. Cell Immunol 2017; 316: 1-10. 